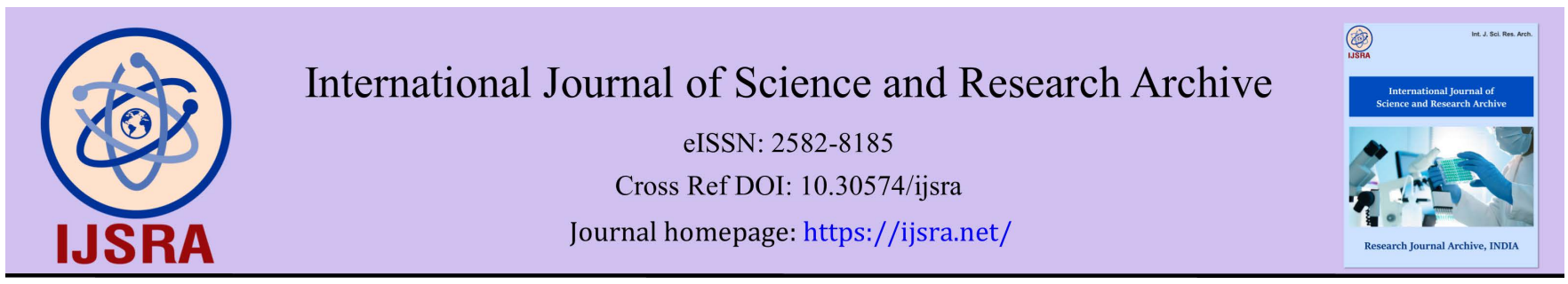

(RESEARCH ARTICLE)

Check for updates

\title{
Influence of competence and job satisfaction on the performance of the state civil apparatus (ASN) in Tonra district of bone regency
}

\author{
Azikin ${ }^{1 *}$, Muhammad Yusuf ${ }^{2}$ \\ ${ }_{1}^{1}$ Departement of Development Economics, College of Economics, YAPTI Jeneponto, Jalan M Ali Gassing No 1, Jeneponto, \\ South Sulawesi, 92315, Indonesia, \\ ${ }^{2}$ Departement of Fisheries Agrobusiness, Cokroaminoto University Makassar, Jl. Perintis Kemerdekaan Km 11, amalanrea \\ Makassar, South Sulawesi, 90245 Indonesia.
}

International Journal of Science and Research Archive, 2021, 03(02), 118-122

Publication history: Received on 20 August 2021; revised on 29 September 2021; accepted on 01 October 2021

Article DOI: https://doi.org/10.30574/ijsra.2021.3.2.0148

\begin{abstract}
One of the main functions of the government is to organize public services as a form of the general duty of government for the welfare of the community, including the government of Tonra District of Bone Regency. Bureaucracy or government services are government instruments to realize efficient, effective, equitable, transparent and accountable public services. The research was conducted at tonra district office of Bone District of South Sulawersi Province. The population in this study is all employees in the tonra district government area numbering 60 people. The type of data in this study is primary data obtained from respondents' answers to a number of questions and statements in questionnaires related to research variable indicators. Research variables consist of independent variables (X1) namely competence, and job satisfaction (X2), as well as dependent variables namely ASN performance (Y). The results of the study obtained that the variables of competence and job satisfaction both partially and simultaneously (together) have a real (significant) effect on the performance of ASN in the scope of the government office of Tonra District of Bone Regency. Thus it can be concluded that the factors of compote and job satisfaction are very important to note in human resource management and institutional/ organizational management, especially in the government office of Tonra District of Bone Regency.
\end{abstract}

Keywords: Competence; Job Satisfaction; Civil Servants; Performance; Tonra district

\section{Introduction}

One of the main functions of government is to organize public services as a form of the general duty of government for the welfare of the community. Bureaucracy is the government's instrument to realize efficient, effective, equitable, transparent and accountable public services [1]. This means that to be able to carry out government functions properly, bureaucratic organizations must be professional, responsive, aspirational to the various demands of society served.

Changes in the field of human resources are followed by changes in the competence and ability of someone who is selfin contact with human resource management. The development of the broader competence of human resource practitioners ensures that human resource management plays an important role in organizational success. Competence is now part of the language of development management, job standards or competency statements have been made for most positions as the basis for determining training and quality of skills. Complement describes the basic knowledge and performance standards required to successfully complete a job or hold a position [2]. Methods used to identify competencies to support the ability to concentrate on behavioral outcomes.

\footnotetext{
* Corresponding author: Azikin

Departement of Development Economics, College of Economics, YAPTI Jeneponto, Jalan M Ali Gassing No 1, Jeneponto, South Sulawesi, 92315, Indonesia.

Copyright (C) 2021 Author(s) retain the copyright of this article. This article is published under the terms of the Creative Commons Attribution Liscense 4.0.
} 
The community hopes that the services provided by the Tonra District Government of Bone Regency can be more easily, smoothly, quickly, precisely, friendly, and there is certainty and clarity of procedures and service requirements that meet public service rules. Tonra District is one of the sub-districts located in the southern part of Bone Regency or located about $40 \mathrm{~km}$ from the Capital of Bone Regency. If you look at the condition of the area that is mostly in the corner of the village (kampung) and the difficulty of the location of the sub-district capital in access, especially for residents who are in the village (village), then it takes a level of excellent service that is where the services provided by the Tonra District government must be excellent, meaning that if it can once come to the district office then all the affairs concerned can be resolved properly. The benchmark of service standards used as guidelines for service implementation and reference for assessment of service quality as obligations and promises of service providers to the community in the framework of quality, fast, easy, affordable, and measurable services is referring to the Regulation of the Minister of Utilization of State Apparatus and Bureaucratic Reform of the Republic of Indonesia Number 15 of 2014 , where the components of service standards related to the service delivery process include requirements, procedures, time periods, services, fees/tariffs, service products, and complaint handling.

Along with this, the construction of the State Civil Apparatus is carried out continuously, in order to be an efficient, effective, clean and authoritative tool, so as to be able to carry out the general duties of the government and to drive development smoothly based on spirit and attitude of community service. Therefore, the Tonra District government as a public servant must be better able to provide maximum service to the community, thus contributing to the creation of a sense of trust in the government. Thus, the improvement of service quality needs to be continuously improved. Therefore, it is important to examine how the influence of competence on job satisfaction and performance of the state civil apparatus (ASN) in Tonra District of Bone Regency.

\section{Material and methods}

\subsection{Time and Location of Research}

The research was conducted at the Tonra District Office of Bone District of South Sulawersi Province. The population in this study is all employees in the tonra district government area of 60 people, including employees in the village. Sampling techniques using saturated samples (census).

\subsection{Types and Sources of Data}

The type of data in this study is primary data obtained from respondents' answers to a number of questions and statements in questionnaires related to research variable indicators. According to [3] primary data is data obtained directly from the research subject either in the form of data or information using established guidelines. Research variables consist of independent variables $\left(\mathrm{X}_{1}\right)$ namely competence, and job satisfaction $\left(\mathrm{X}_{2}\right)$, as well as dependent variables namely ASN performance (Y).

Competence $\left(\mathrm{X}_{1}\right)$ is the knowledge, skills, and qualities of individuals to achieve job success [4].

Job Satisfaction $\left(\mathrm{X}_{2}\right)$ is an emotionally pleasing or unpleasant attitude of employees towards their work compared to the return of services received in accordance with expectations $[5,6,7]$.

Employee Performance (Y) is the achievement produced by employees in carrying out the tasks charged based on proficiency, experience and earnestness and time [8].

\subsection{Data analysis}

The data analysis method used to analyze the influence of competency variables on job satisfaction and ASN performance is a real different test with the $t$ test technique and f test (Anova). The analysis is intended to answer the hypothesis built as follows:

There is a competency influence on the performance of ASN in tonra subdistrict office.

There is an effect of job satisfaction on the performance of ASN in Tonra District Office. 


\section{Results and discussion}

\subsection{Partial Test (Uji-T)}

The $\mathrm{T}$ test is intended to determine the effect of each independent variable on the dependent variable partially or individually, in this case how the effect of complementation $\left(\mathrm{X}_{1}\right)$ affects the performance of ASN (Y), and how the effect of ASN job satisfaction $\left(\mathrm{X}_{2}\right)$ affects the performance of ASN (Y). Here are the results of statistical analysis of real different tests (t-test).

Table 1 Partial test output (T test)

\begin{tabular}{|c|c|c|c|c|c|c|}
\hline \multicolumn{7}{|c|}{ Coefficients $^{\mathrm{a}}$} \\
\hline \multirow{2}{*}{\multicolumn{2}{|c|}{ Model }} & \multicolumn{2}{|c|}{$\begin{array}{l}\text { Unstandardized } \\
\text { Coefficients }\end{array}$} & \multirow{2}{*}{$\begin{array}{l}\text { Standardized } \\
\text { Coefficients }\end{array}$} & \multirow[t]{2}{*}{$\mathbf{t}$} & \multirow[t]{2}{*}{ Sig0. } \\
\hline & & B & Std0. Error & & & \\
\hline \multirow[t]{3}{*}{1} & (Constant) & 0.335 & 20.310 & - & 0.245 & 0.680 \\
\hline & Compoteance $\left(\mathrm{X}_{1}\right)$ & 0.250 & 0.017 & 0.264 & 20.408 & 0.014 \\
\hline & Satisfaction $\left(\mathrm{X}_{2}\right)$ & 0.275 & 0.019 & 0.315 & 20.740 & 0.005 \\
\hline
\end{tabular}

The results of the t-test analysis showed that the compoter variable $\left(\mathrm{X}_{1}\right)$ had a real effect on the ASN performance variable (Y). This is evident from the value of t-count $(2,408)$ greater than the value of t-table $(2,002)$ with the free degree $\mathrm{df}=\mathrm{n}-\mathrm{k}(60-3=57)$ with a confidence interval of $95 \%$ or an error tolerance of $5 \%(0.05)$. Similarly, for the satisfaction variable $\left(\mathrm{X}_{2}\right)$ partially or individually has a real (significant) effect on the asn performance variable (Y). This is evident from the results of the t test analysis obtained the value $t$-calculated $(2,740)>$ the value of $t$-table $(2,002)$, which means reject $\mathrm{H}_{0}$ and receive $\mathrm{H}_{1}$. In addition, it also appears in the value sig. $<0.05$ which means that the two variables are significant (real) have a correlation/ relationship or affect the performance of ASN (Y).

The results obtained in line with [9] that the level of job satisfaction is one of the factors that affect work performance that ultimately affects organizational effectiveness. The results of the study are also in accordance with the results of research by [10] which states that job satisfaction is important in determining behavior and response to work and with that behavior, so that effective organization will be achieved. The relationship between job satisfaction and performance usually occurs at a certain level, or in certain circumstances and positions where people are at the manager level. [11] states that job satisfaction affects performance assuming employees will give the best for the organization when they get the best out of the organization they work for. Therefore, in an organization the need to set performance assessment standards based on the results of certain work processes in a planned manner at the time and place of employees, as well as the organization concerned, because performance measurements must be based on something measurable in accordance with established standards [12].

\subsection{Simultaneous Test (F-Test)}

The F test is a statistical test or hypothesis test intended to determine whether there is a significant influence of the overall independent variable $(\mathrm{X})$ together (simultaneously) in this case the effect of the variable computence $\left(\mathrm{X}_{1}\right)$, and satisfaction $\left(\mathrm{X}_{2}\right)$ on the dependent variable $(\mathrm{Y})$ i.e. ASN performance.

The results of the analysis show that simultaneously (simultaneously) both independent variables are; Complement $\left(\mathrm{X}_{1}\right)$, and satisfaction $\left(\mathrm{X}_{2}\right)$ have a noticeable (significant) effect on asn performance variables (Y). This is evident from sig value. 0.00 is less than the alpha value of 0.05 which means there is a significant influence. In addition, it is also seen in the value of F-count (6.015) greater than the $>$ F-table $(2,770)$ obtained from the $N 1=d f 1=k-1(4-1=3)$ and $N 2=d f 2=n-$ $\mathrm{k}(60-3=57)$. Thus it can be concluded that together (simultaneously) the two independent variables have a noticeable (significant) influence on the dependent variable. In other words, that compote, and job satisfaction have a real influence on the performance of ASN in tonra district office, Bone Regency. Compotence, and job satisfaction became a significant factor affecting the performance of ASN in the scope of the government office of Tonra Subdistrict, Bone Regency. In other words, it can be concluded that the performance of ASN in the scope of the government office of Tonra Subdistrict, 
Bone Regency is the result of a work process, which is influenced by competence, and job satisfaction simultaneously. To be able to grow and develop government, then the two factors together are the key to achieving the success of excellent service to the community. This is in accordance with the results of research by [13] that there is an influence of competence on the performance of employees in the regional secretary of Sidenreng Rappang Regency.

The results of the test analysis in unison with the Anova approach are obtained as follows:

Table 2 Simultaneous test analysis output (Anova)

\begin{tabular}{|l|l|l|l|l|l|l|}
\hline \multicolumn{7}{|l|}{ ANOVA } \\
\hline \multicolumn{2}{|l|}{ Model } & Sum of Squares & df & Mean Square & F & Sig. \\
\hline \multirow{3}{*}{1} & Regression & 63.950 & 3 & 20.650 & 6.015 & $0.000 \mathrm{~b}$ \\
\cline { 2 - 7 } & Residual & 213.281 & 57 & 4.561 & & \\
\cline { 2 - 7 } & Total & 277.231 & 60 & & & \\
\hline \multicolumn{2}{|l|}{ a. Dependent Variable: ASN Performance } \\
\hline
\end{tabular}

\section{Conclusion}

Based on the results of statistical test analysis obtained that the variables of competence and job satisfaction both partially and simultaneously (together) have a real (significant) effect on the performance of ASN in the scope of the government office of Tonra District bone district. Thus it can be concluded that the factors of compote and job satisfaction are very important to note in human resource management and institutional / organizational management, especially in the government office of Tonra District of Bone Regency.

\section{Compliance with ethical standards}

\section{Acknowledgments}

Thank you for the collaboration between the two universities, namely; Economics College of YAPTI Jeneponto and Cokroaminoto University Makassar. Thank you to the head of government of Tonra District, Bone Regency and staff for cooperation during the research took place.

\section{Disclosure of conflict of interest}

In principle we do not have a conflict of interest, considering our role and field of study which is different.

\section{Statement of informed consent}

All information and statements obtained from respondents (informants) are for research purposes and will be maintained.

\section{References}

[1] Mahsun, Mohammad. Pengukuran Kinerja Sektor Publik. Edisi ketiga BPFE. Yogyakarta. 2009

[2] Mangkunegara, Anwar Prabu. Evaluation of Human Resource Performance. Bandung: PT. Reflika Aditama. 2006

[3] Yusuf, M \& Daris, L. Analysis of Research Data; Theory \& Application in Fisheries. PT. IPB Press. Bogor. 2018

[4] Amstrong Michael. Manajemen Sumber Daya Manusia. PT. Elexmedia Komputindo. Jakarta. 2005

[5] Luthans, Fred. Organization Behavior Of Edition Ten. Translation: Vivin Andhika. Yogyakarta: Andi. 2006

[6] Hasibuan, Malayu S P. Human Resource Management. Revised Edition. Jakarta: PT. Bumi Aksara. 2012

[7] Rivai, Veithzal. Human Resource Management for the Company. Second Edition. Jakarta: PT. Raja Grafindo Persada. 2010

[8] Martoyo, Susilo. 2007. Human Resource Management. 5th Edition. First Print. Yogyakarta: BPFE. 
[9] Handoko, T. Hani. Personnel and Human Resources Management. BPFEE- Yogyakarta. 2014

[10] Dessler, Gary. Human Resource Management, Himan Resource Management 7e. PT Prehallindo, Jakarta. 2005

[11] Callista, Natasha. The Influence of HR Competence on Employee Performance on PT. Tresnamuda Sejati Surabaya Branch. AGORA 2016; Vol. 4, No. 2:45-50.

[12] Mulyanto dan Mini Setiyarti. Influence of Organizational Commitment and Work Discipline on Performance Satisfaction in An Effort to improve employee performance. Journal of Economics and Entrepreneurship. 2013; Vol.13. No. 1.

[13] Namirah Mardin Amin. The Influence of Competence on Employee Performance in the Regional Secretary of Sidenreng Rappang Regency. Thesis. Universitas Hasanuddin. 2015. 